\title{
Analysis of emission tests of electromagnetic disturbances in diesel-electric locomotives
}

\author{
Andrzej Białoń, Kamil Białek ${ }^{*}$, and Patryk Wetoszka \\ Railway Research Institute, 50 Chlopickiego Jozefa Street, Poland
}

\begin{abstract}
This paper discussed the measurement of radiated emissions of electromagnetic disturbances generated by diesel - electric locomotive system. The measurement methodology, permissible values of a magnetic and electric field according to EN 50121-3-1 standard during driving and standstill for electric diesel locomotive are presented. The article presents examples of test results and an assessment of the obtained measurement results in the electric and diesel traction according to the applicable requirements.
\end{abstract}

\section{Introduction}

In the railway area there are intentional and unintentional (stationary and non-stationary) sources of electromagnetic radiation that can interfere with the operation of electrical and electronic systems and devices. In the railway electromagnetic environment we distinguish the following sources of electromagnetic interference:

- stationary - derived from the traction network, power network supplying traction substations and the power supply line for railway traffic control systems,

- moving - disturbances generated by traction vehicles (electric traction units, electric and diesel locomotives).

Modern rail vehicles are equipped with devices, electrical and electronic systems that can be a potential source of interference, ie traction inverters, static converters, asynchronous motors, air conditioning systems, passenger information, safety (European Train Control System - ETCS), automatic braking of the train SHP, dead man's active equipment, communication devices (eg GSM-R, VHF radiotelephones), etc. The devices and systems used on rail vehicles are miniaturized, limited power consumption and high reliability of operation $[3,4]$. The introduction of these design constraints is associated with an increase in the probability of the level of disturbances generated by traction vehicles. Therefore, such an important problem is the continuous analysis of the state of the electromagnetic environment in the aspect of the intensity of the magnetic and electric field generated by rail vehicles moving along the railway route (electromagnetic environment diagnostics).

\section{Measurement of emission of electromagnetic disturbances of radiated diesel-electric locomotive}

\subsection{Measurement methodology}

The tests of electromagnetic compatibility of radiated radiation emissions are carried out in accordance with EN 50121-3-1 [1] standard in the frequency band of 150 $\mathrm{kHz} \div 1 \mathrm{GHz}$ divided into two subband:

- measurement of the magnetic component of the field strength (the band $150 \mathrm{kHz} \div 30 \mathrm{MHz}$ ),

- measurement of the electrical component of the field strength (the band $30 \mathrm{MHz} \div 1 \mathrm{GHz}$ ).

To measure the magnetic field strength component, a frame (loop) antenna is used, while for measuring the electrical component a double-cone antenna and a logand-periodic antenna. Figure 1 shows the permissible magnetic and electric field strengths for a traction vehicle (eg a diesel-electric locomotive) [4].

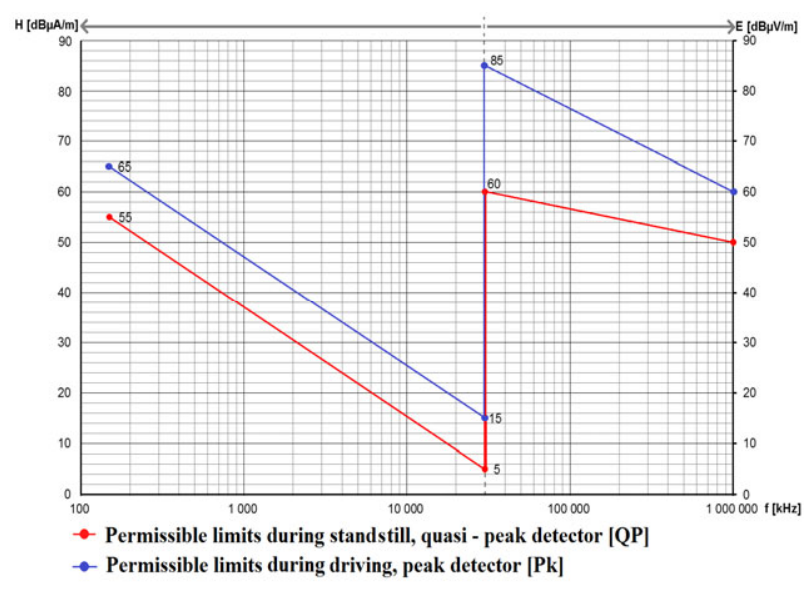

Fig. 1. Values for radiated disturbances for a traction vehicle (eg diesel and electric locomotive) [4]. 
The measurements of the electromagnetic field intensity are carried out on the Experimental Track of the Railway Institute in Żmigród, on the railway track or standstill tracks, where the requirements of EN 55016-42 [2] (no trees, substations, transformers and railway traffic control equipment) within a radius of $30 \mathrm{~m}$ are met. Other traction vehicle should not be on the same power section at a distance of at least $1 \mathrm{~km}$ from the tested locomotive. Before testing radiation disturbances generated by rail vehicles, should be measured the background of the electromagnetic field environment in the frequency ranges given in the table below - Table. 1 .

Table 1. Frequency range for background and driving mode [1]

\begin{tabular}{|c|c|c|}
\hline Subrange $[\mathrm{Hz}]$ & Bandwidth $[\mathrm{kHz}]$ & Sweep time [ms] \\
\hline $150 \mathrm{k} \div 1,15 \mathrm{M}$ & 9 lub 10 & 37 \\
\hline $1 \mathrm{M} \div 11 \mathrm{M}$ & 9 lub 10 & 370 \\
\hline $10 \mathrm{M} \div 20 \mathrm{M}$ & 9 lub 10 & 370 \\
\hline $20 \mathrm{M} \div 30 \mathrm{M}$ & 9 lub 10 & 370 \\
\hline $30 \mathrm{M} \div 230 \mathrm{M}$ & 100 lub 120 & 42 \\
\hline $200 \mathrm{M} \div 500 \mathrm{M}$ & 100 lub 120 & 63 \\
\hline $500 \mathrm{M} \div 1 \mathrm{G}$ & 100 lub 120 & 100 \\
\hline
\end{tabular}

The level of external disturbances - produced by other sources of the electromagnetic field should be lower by at least $6 \mathrm{~dB}$ from the permissible levels (Figure 1). If the measurement of the background electromagnetic field strength exceeds $-6 \mathrm{~dB}$ for a frequency band, then this range should not be taken into account in the assessment of the results $[1,3,6]$.

The diesel - electric locomotive is tested in two states: during standstill and while driving at a speed (50 $\pm 10) \mathrm{km} / \mathrm{h}$. During this time all systems must be activated (air conditioning system, ETCS European Train Control System, passenger information system, communication devices, etc.), internal and external lighting on the vehicle. In the case of tests at a standstill, the measuring point should be determined by means of a test run as follows: the vehicle moves at a speed of about $10 \mathrm{~km} / \mathrm{h}$ in front of the antennas in order to read the field strength value at the receiver. After the test run, the locomotive is placed in the place where the highest level of radiated disturbances is generated. The measurement is performed with a quasi-peak detector $[3,4,8,9]$.

The tests must be carried out while driving a locomotive as electric and diesel. In the case of testing the locomotive while driving, the vehicle should accelerate or slow using $1 / 3$ of the maximum traction in a given speed range. The measurement is performed with a quasi-peak detector. The measuring antennas for the above mentioned operating modes are set at a distance of $10 \mathrm{~m}$ from the axis of the track and are placed at different heights depending on the type of antenna used:

- frame - $1 \mathrm{~m} \div 2 \mathrm{~m}$ above the rail head,

- double conical and logarithmic - periodic $2.5 \mathrm{~m} \div 3.5$ $m$ above the rail head.

The height of the antenna is selected so as to obtain the maximum level of emitted electromagnetic field disturbances. Measurements should be made for the polarization of the vertical and horizontal antennas (Vvertical and H-horizontal). After completing the tests while the vehicle is stationary and while driving, the level of electromagnetic disturbances BACKGROUND. Examples of measuring stations are shown in Figures 2, 3 and 4.

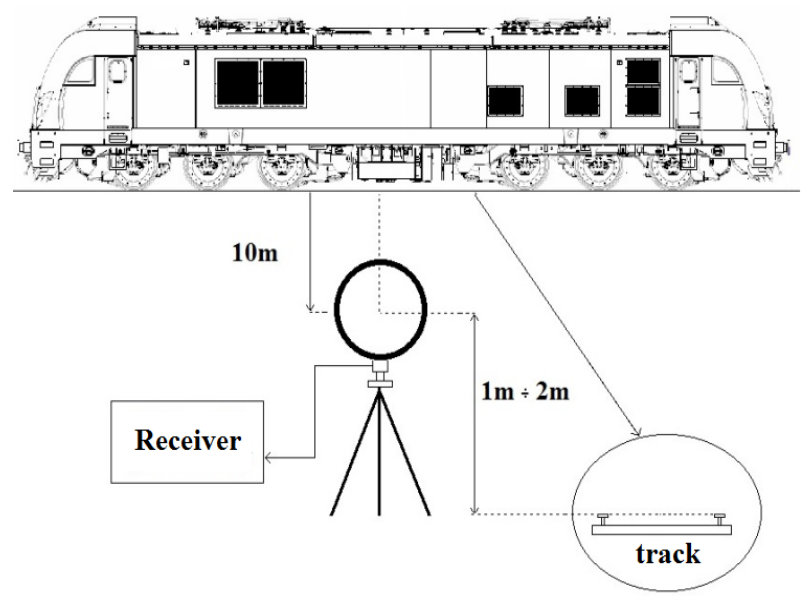

Fig. 2. Measurement of emission of radiated disturbances in the frequency band of $150 \mathrm{kHz} \div 30 \mathrm{MHz}$ with the use of a frame antenna.

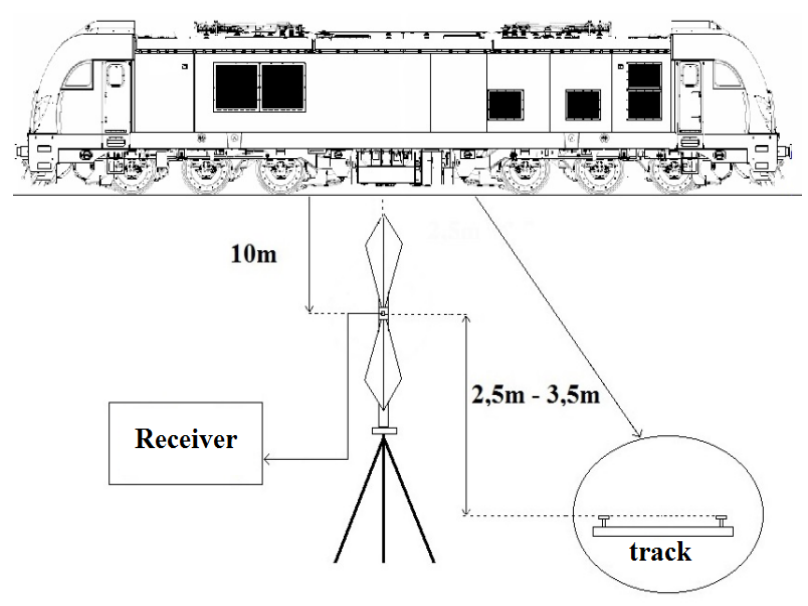

Fig. 3. Measurement of radiated emission in the $30 \mathrm{MHz} \div 230$ $\mathrm{MHz}$ frequency band using a double-cone antenna.

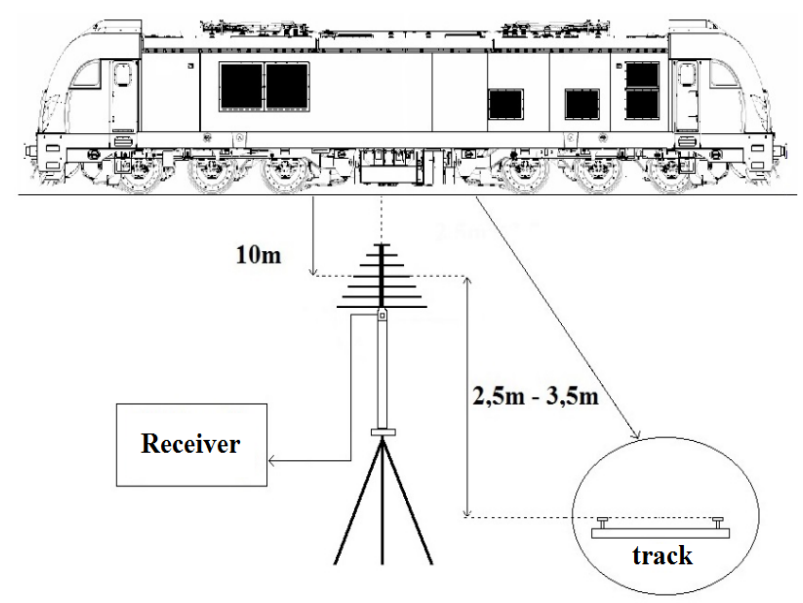

Fig. 4. Measurement of emission of radiated disturbances in the frequency band $230 \mathrm{MHz} \div 1 \mathrm{GHz}$ with the use of a logarithmic-periodic antenna. 


\subsection{Results of measurements of disturbances of radiated diesel and electric locomotive}

The following are examples of the results of an exploration of an electric and diesel locomotive made on the Experimental District of the Railway Institute for a locomotive working in the electric and diesel traction. In the case of electric traction, the traction vehicle was powered with $3 \mathrm{kV}$ DC.

During the research on the locomotive all electrical, electronic and electrotechnical systems were included, which are used during normal operation (they take a certain current and generate conducted or radiated disturbances) [7]. The auxiliary systems were powered by means of a static converter. The measurements were made using a receiver and three measurement antennas: frame, double-cone and logarithmic - two-way for two modes of operation: standstill and driving. Tests using a double-cone and logarithmic antenna were made for both antenna polarization: vertical and horizontal. During the test standstill measuring antennas it was opposite the static converter and the locomotive inverter. In the case of testing during driving, the vehicle is traveling at a speed of $50 \mathrm{~km} / \mathrm{h}$ at $1 / 3$ of the maximum tractive force in a given speed range $[1,5,9,11]$.

Figure 6 shows a double-cone antenna with a mast during the measurement of emission of electromagnetic environment disturbances (BACKGROUND - also referred to in the literature on electromagnetic compatibility electrosmog). The background during the tests was measured before and after the measurements.

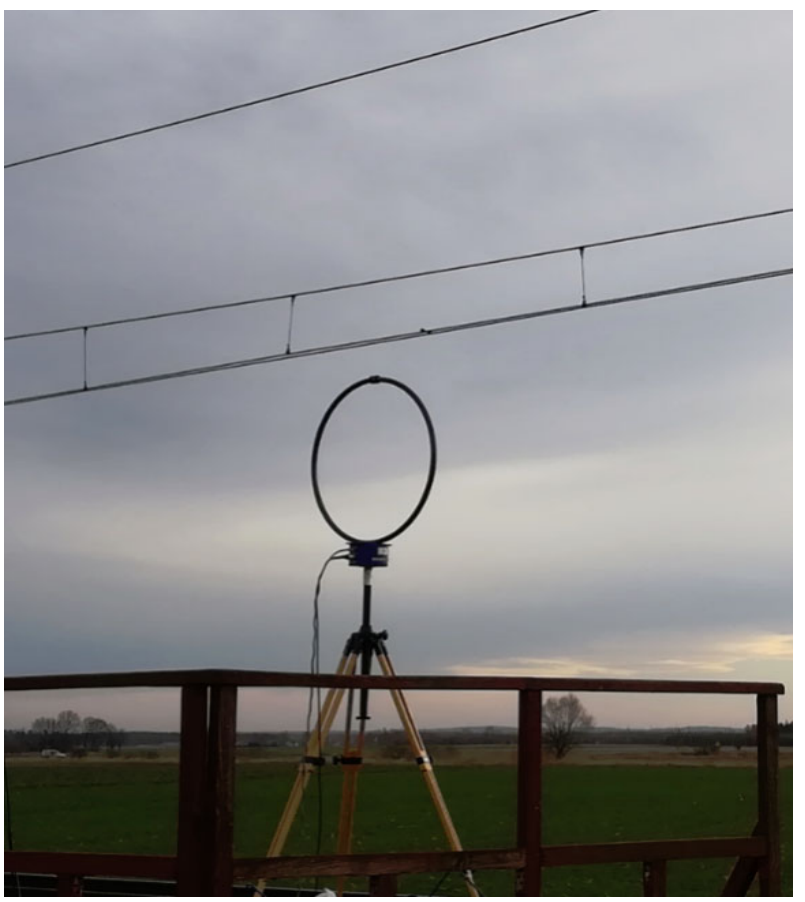

Fig. 5. Frame antenna during measurement of emission of electromagnetic environment disturbances (BACKGROUND).

Figures 6 to 14 present examples of the results of emission of electromagnetic disturbances radiated generated by a locomotive working in the electric and diesel traction in the frequency bands defined by the EN 50121-3-1 standard [1] and presented in Table 1.

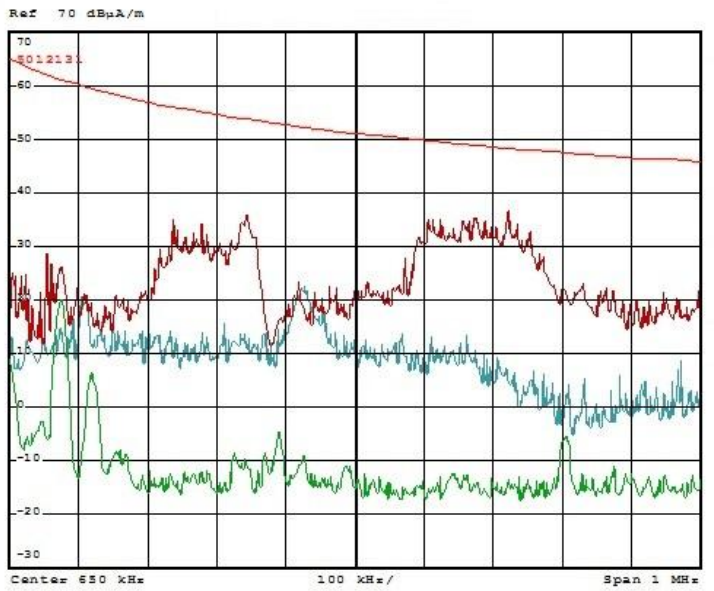

Background,

Driving $50 \mathrm{~km} / \mathrm{h}$ - diesel traction,

Driving $50 \mathrm{~km} / \mathrm{h}$ - electric traction

Fig. 6. The value of the emission of magnetic disturbances while driving, the band $150 \mathrm{kHz}-1.15 \mathrm{MHz}$.

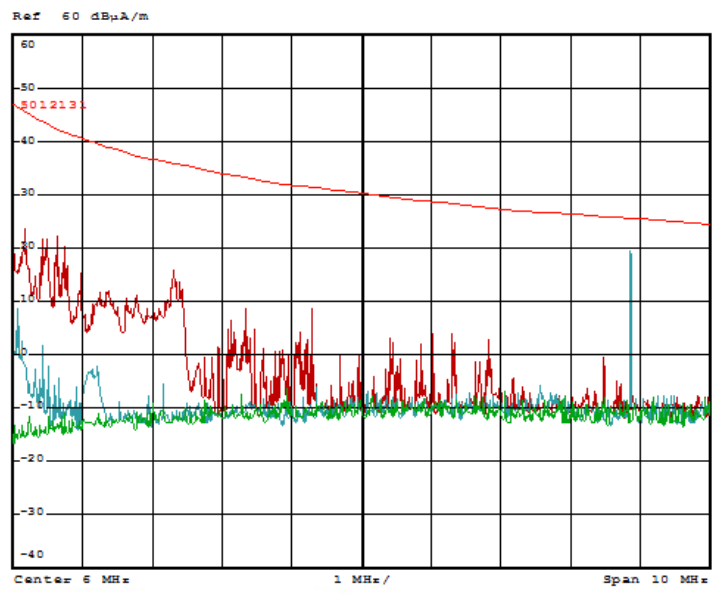

Background,

Driving $50 \mathrm{~km} / \mathrm{h}$ - diesel traction,

Driving $50 \mathrm{~km} / \mathrm{h}$ - electric traction

Fig. 7. The value of the emission of magnetic disturbances while driving, the band $1 \mathrm{MHz}-11 \mathrm{MHz}$.

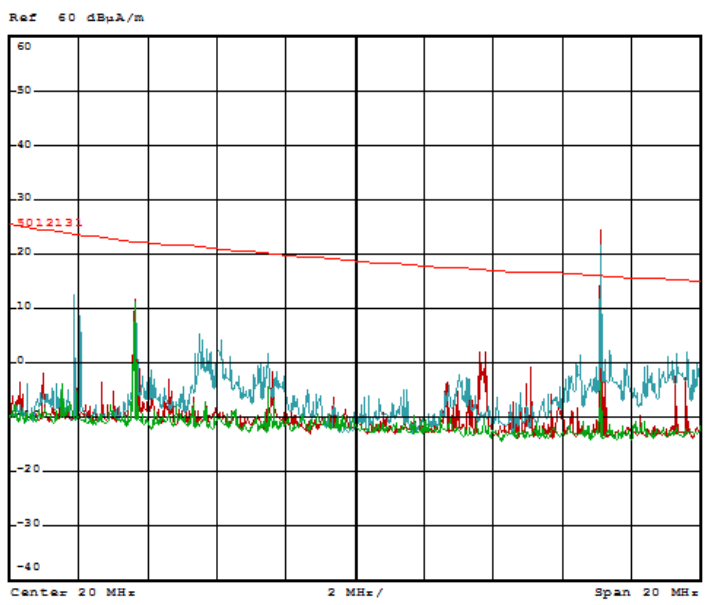

Background,

Driving $50 \mathrm{~km} / \mathrm{h}$ - diesel traction,

Driving $50 \mathrm{~km} / \mathrm{h}$ - electric traction

Fig. 8. The value of the emission of magnetic disturbances while driving, the band $10 \mathrm{MHz}-30 \mathrm{MHz}$. 


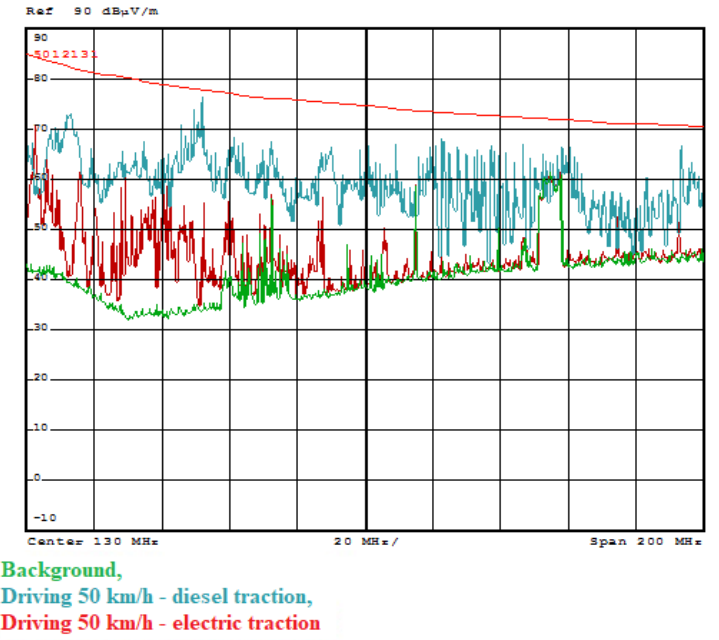

Fig. 9. The value of emission of electrical disturbances for vertical polarization of the antenna while driving, the band $30 \mathrm{MHz}-230 \mathrm{MHz}$.

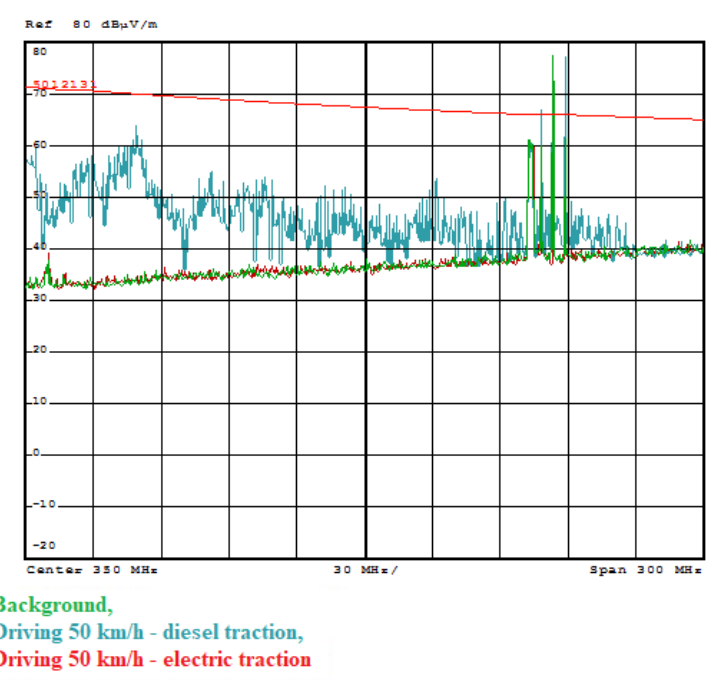

Fig. 10. The value of emission of electrical disturbances for vertical polarization of the antenna while driving, the band $200 \mathrm{MHz}-500 \mathrm{MHz}$.

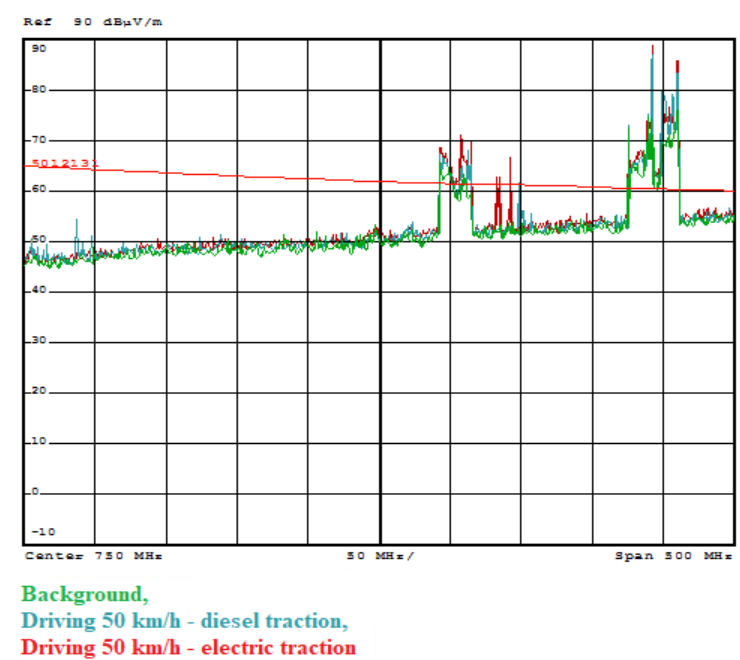

Fig. 11. The value of emission of electrical disturbances for vertical polarization of the antenna while driving, the band $500 \mathrm{MHz}-1 \mathrm{GHz}$.

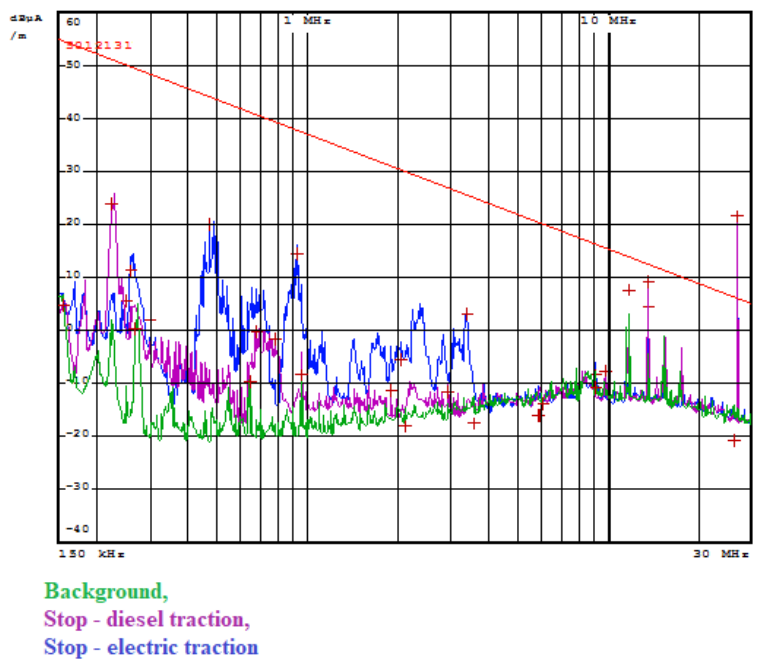

Fig. 12. The value of the emission of magnetic disturbances at a standstill, the band $150 \mathrm{kHz}-30 \mathrm{MHz}$.

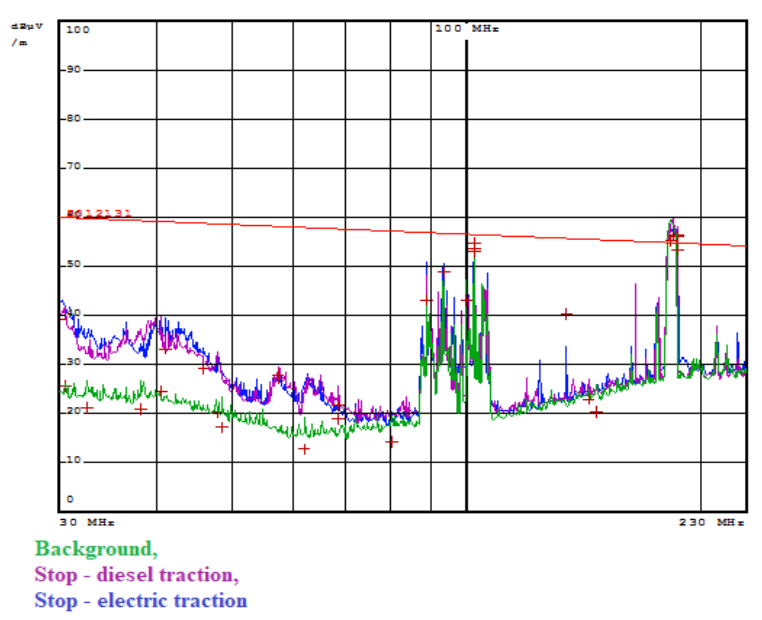

Fig. 13. The value of emission of electrical disturbances at a standstill for the vertical polarization of the antenna, the band $30 \mathrm{MHz}-230 \mathrm{MHz}$.

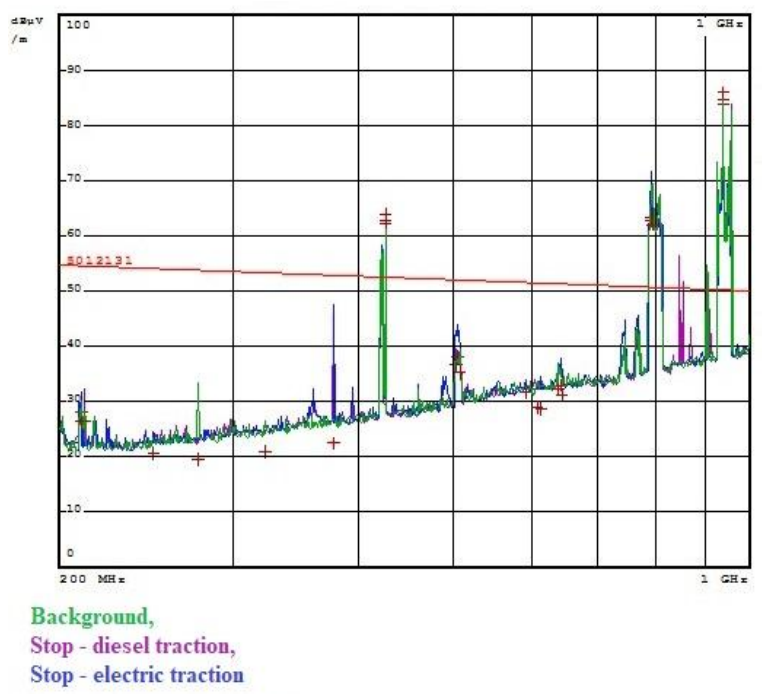

Fig. 14. The value of emission of electrical disturbances at a standstill for the vertical polarization of the antenna, the band $200 \mathrm{MHz}-1 \mathrm{GHz}$. 
The presented measurement results take into account the applied measurement path in the electromagnetic field measurement system, the amplification / attenuation coefficients of the antennas and the attenuation of the cable as a function of frequency.

The presented results show that a locomotive working in the diesel traction system generated a higher level of electromagnetic disturbances. Measurements have shown that the source of elevated levels of disturbances in relation to the locomotive working in the electric traction is the generator set installed on the locomotive.

During the tests, values exceeding the permissible emission levels of radiated disturbances determined according to EN 50121-3-1 [1] were measured. The exceedances occurred on frequencies $427 \mathrm{MHz}$ and in the bands respectively equal to: $790 \mathrm{MHz}-820 \mathrm{MHz}$ and $925 \mathrm{MHz}-970 \mathrm{MHz}$ for two modes of operation: driving and standstill.

During the emission tests of radiated disturbances, the exceeding of the limit value on the $27 \mathrm{MHz}$ frequency was also recorded in the driving and standstill. The source of exceedances is the balis antenna designed for communication in the ETCS vehicle-track system [9, $10,11]$. This overrun can be omitted as originating from a source intentionally placed in the railway system, which is in accordance with EN 50121-3-1 [1].

Pursuant to the recommendations of EN 50121-3-1 [1], the above ranges have not been evaluated because the values of external electromagnetic disturbances (Background) exceed the permissible level - $6 \mathrm{~dB}$. The source of measured electromagnetic fields that reach high values are radiolocation and radio stations, navigation and telecommunications devices operating in the above frequency bands.

There were no exceedances of acceptable levels according to EN 50121-3-1 [1], the source of which is an electric-diesel locomotive.

\section{Summary}

The article presents the measurement of electromagnetic disturbances generated by a locomotive working in the electric and diesel traction. Measurements are carried out in the frequency range from $150 \mathrm{kHz} \div 1 \mathrm{GHz}$ for two operating modes: driving and standstill with the use of three measurement antennas: frame (loop), double-cone and logarithmic-periodic.

The sources of interference occurring on an electricdiesel locomotive with impulse control can be divided into two groups:

- external source that produces interference due to violation of uniform current collection during slipping pantograph on the contact wire - external source of interference,

- internal sources inside the vehicle body, i.e. traction motors, impulse systems, auxiliary equipment, power generator in the case of a locomotive operating in the traction system.

The locomotive working in the diesel traction generated a higher level of electromagnetic disturbances, because worked additional power generator on the vehicle. The measurements carried out allow to state that that traction vehicles have large an effect on the railway electromagnetic environment. The level of the intensity of the electromagnetic field generated by vehicles moving along the railway routes depends on many factors, e.g. vehicle type, pantograph structure, power system, energy conversion method, vehicle speed, etc.

\section{References}

1. EN 50121-3-1:2016 Railway applications Electromagnetic compatibility - Part 3-1: Rolling stock - Train and complete vehicle

2. EN 55016-4-2:2011 Specification for radio disturbance and immunity measuring apparatus and methods - Part 4-2: Uncertainties, statistics and limit modelling - Measurement instrumentation uncertainty

3. Charoy A., Kompatybilność elektromagnetycznazakłócenia $w$ urzadzeniach elektronicznych, tom 13, Warszawa 1999-2000

4. Białek K., John Ł.: Pomiary emisji zaburzeń od kolejowych pojazdów szynowych pracujacych $w$ trakcji wielokrotnej, Przegląd elektrotechniczny; 03/2019 Str. 14; 00-950 Warszawa

5. Williams T., EMC for product designer, Nedition Newnes (1992)

6. Mark I. Montrose, Edward M. Nakauchi Testing for EMC Compliance: Approaches and Technigues, IEEE (2014).

7. Donald G. Baker Electromagnetic Compatibility Analysis and Case Studies in Transportation, WILEY \& Sons (2016).

8. Laskowski M., Dłużniewski A., John Ł.: Problematyka generacji zaburzeń radioelektrycznych oraz ich pomiary $w$ środowisku kolejowym, Przegląd Telekomunikacyjny, nr 11 (2013).

9. Białoń A., Dłużniewski A., John Ł.: Kompatybilność elektromagnetyczna taboru miejskiego i kolejowego - wymagania normatywne, Przegląd Telekomunikacyjny, nr 10/2011, str. 767768 (2011).

10. Białoń A., Gradowski P., Torun A.: Nowoczesny system zarządzania ruchem kolejowym (ERTMS), Problemy Kolejnictwa Railway Reports, issue nr 148, ISSN 0552-2145, Railway Research Institute, pp. 140, 144, 148-152 (2009).

11. Gradowski P.: Upgrading the railway infrastructure technical parameters using the example of the Control-Command and Signalling subsystem with the EC verification certificate, Railway Reports, issue 182 (March 2019), ISSN 0552-2145, Railway Research Institute, Warsaw, pp. 131-146 (2019). 